\title{
EDUKASI VAKSINASI COVID-19 BAGI KELOMPOK AISYIAH RANTING KUKUSAN DEPOK
}

\author{
Eka kartikawati'1), Mayarni'1) \\ 1)Pendidikan Biologi, FKIP, Universitas Muhammadiyah Prof. Dr. Hamka, Jakarta, Indonesia
}

Corresponding author : Eka Kartikawati

E-mail : eka.kartikawati@uhamka.ac.id

\author{
Diterima 07 Juli 2021, Direvisi 25 Juli 2021, Disetujui 26 Juli 2021
}

\begin{abstract}
ABSTRAK
Upaya pemerintah dengan memberikan vaksinasi kepada warga masyarakat sebagai bentuk pencegahan covid-19 masih dirasa pro dan kontra oleh masyarakat, menurut survei masih banyak warga yang masih takut tentang keampuhan serta kefektifan dari vaksinasi tersebut. Faktor lainnya juga karena terdapat pemberitaan yang tidak sesuai yang banyak beredar sehingga masyarakat masih belum banyak yang mengetahui lebih jelas mengenai vaksinasi tersebut. Untuk meluruskan hal tersebut maka perlu adanya edukasi mengenai pentingnya vaksinasi covid-19. Hal ini bertujuan agar khususnya warga aisyiah ranting kukusan memperoleh informasi yang sesuai serta tidak ada lagi ketakutan mengenai pemberian vaksin. Selain itu dilakukan juga pelatihan pembuatan disinfektan kepada ibu-ibu warga aisyiah kukusan depok sebagai upaya pencegahan covid-19. Beberapa langkah yang dilakukan dalam kegiatan pengabdian ini yaitu 1) sosialisasi langsung mitra aisyiah ranting kukusan depok 2) pemberian edukasi mengenai vaksinasi covid-19 3) pelatihan pembuatan disinfektan 4) penyemprotan lingkungan lembaga 5) evaluasi akhir kegiatan. Hasil kegiatan ini bahwa mitra dapat memahami dengan jelas yakni mengenai vaksinasi, cara kerja vaksinasi, kriteria yang boleh dan tidak boleh di vaksinasi, reaksi vaksinasi terhadap tubuh dan herd immunity serta pembuatan disinfektan.
\end{abstract}

Kata kunci: edukasi; vaksinasi; covid-19; disinfektan

\begin{abstract}
The government's efforts by giving vaccinations to citizens as a form of prevention of COVID-19 are still considered pros and cons by the community, according to the survey, there are still many residents who are still afraid about the efficacy and effectiveness of the vaccination. Another factor is because there is a lot of inappropriate news circulating so that many people still don't know more clearly about the vaccination. To straighten this out, it is necessary to provide education about the importance of covid19 vaccination. This is intended so that especially the residents of the Steamed Branch Aisyiah get the appropriate information and there is no more fear about giving vaccines. In addition, training on the manufacture of disinfectants was also carried out for the women of Aisyiah Kusan Depok residents in an effort to prevent COVID-19. Several steps were taken in this service activity, namely 1) direct socialization of aisyiah partners of the Depok Steam Branch 2) providing education regarding the covid19 vaccination 3) training on making disinfectants 4) spraying the environment of the institution 5) final evaluation of the activity. The result of this activity is that partners can understand clearly about vaccination, how vaccination works, criteria that may and may not be vaccinated, reactions to vaccination against the body and herd immunity and the manufacture of disinfectants.
\end{abstract}

Keywords: education; vaccination; covid-19; disinfectant.

\section{PENDAHULUAN}

Virus corona sudah berjalan di tahun kedua menyebar di Indonesia. Melihat tingginya angka penyebaran covid-19 maka pemerintah mengeluarkan adanya kebijakan mengenai vaksinasi covid-19 di Indonesia. Pemberlakuan tersebut membuat masyarakat mempunyai pandangan yang bebeda mengenai hal tersebut. Berdasarkan hasil survei masyarakat pada media sosial, sebanyak $49,9 \%$ dari 601 responden tidak menyetujui sebagai penerima vaksinasi covid-19 (Kusumaningtyas, 2021).

Salah satu cara yang dapat memutus penyebaran covid-19 adalah dengan vaksinasi. Vaksin bukan hanya sebagai perlindungan untuk masyarakat yang di vaksinasi namun juga untuk memutus penyebaran suatu penyakit dalam suatu populasi (Syamaidzar, 2020). Selain vaksin digunakan sebagai pemutus dan pencegahan tingkat penyebaran suatu penyakit pada masa yang akan datang, ternyata vaksin 
dapat memperkecil dampaknya terutama disebabkan karena virus yang penyebarannya sangat pesat (Rachman \& Pramana, 2020). Namun Informasi mengenai vaksinasi covid-19 tidak hanya yang pro saja tetapi ada persepsi masyarakat yang justru menolak karena masih meragukan suatu kefektifan, keamanan serta keampuhan dari vaksinasi covid-19 tersebut. Sebenarnya hal tersebut adalah suatu kewajaran karena mengingat covid-19 ini disebabkan oleh virus corona yang terbilang masih baru dan termasuk vaksin yang akan digunakan juga pastinya masih bersifat baru (Rachman \& Pramana, 2020).

Hal lain karena adanya banyaknya informasi yang tidak sesuai, tidak valid, serta tidak dapat dipertanggungjawabkan sehingga mengakibatkan adanya pemberitaan yang diinformasikan kepada masyarakat. Orang yang berusia lanjut adalah suatu kelompok yang sangat rentan terhadap suatu penyakit namun hanya sebagian kecil yang mempunyai sikap dan patuh terhadap pencegahan covid-19 (Daoust, 2020).

Hal inilah yang menjadikan latar belakang tim Universitas Muhammadiyah Prof. Dr. Hamka (UHAMKA) dalam melakukan kegiatan untuk memberikan edukasi mengenai pentingnya vaksinasi Covid-19. Hal ini bertujuan agar khususnya warga aisyiah ranting kukusan memperoleh informasi yang sesuai serta tidak ada lagi ketakutan mengenai pemberian vaksin. Selain itu dilakukan juga pelatihan pembuatan disinfektan kepada ibu-ibu warga aisyiah kukusan depok sebagai upaya pencegahan covid 19.

\section{METODE}

Kegiatan pengabdian ini dilaksanakan di aisyiah ranting kukusan depok. Sosialisasi mengenai edukasi pentingnya vaksinasi tersebut dilakukan lebih khusus kepada warga aisyiah yang mempunyai informasi yang sedikit mengenai vaksinasi terutama dalam pencegahan covid-19. Permasalahan dari mitra kami dirumuskan menjadi dua bagian, yaitu:

1. Minimnya informasi mengenai vaksinasi covid-19

2. Menumbuhkan sikap peduli lingkungan dalam mencegah penyebaran covid-19 dengan membuat disinfektan secara mandiri serta penyemprotannya.

Target sebagai tujuan yang ingin dicapai adalah memperoleh informasi yang sesuai serta tidak ada lagi ketakutan mengenai pemberian vaksin yang valid. Dan diharapkan informasi yang diberikan mengenai vaksinasi seperti keunggulannya dan kemungkinankemungkinan yang terjadi dapat membuka mata masyarakat untuk bersedia di vaksinansi sebagai bentuk pencegahan terkenanya covid19. serta mitra dapat membuat disinfektan sendiri untuk melakukan kebersihan lingkungan dan pencegahan covid- 19 .

Kegiatan yang telah dilakukan dalam pengabdian ini yaitu pertama dengan Tahap Persiapan yang dimulai dengan meminta izin serta berkoordinasi dengan ketua aisyiah ranting kukusan depok, melakukan pendataan serta analisis masalah dan solusi. Tahap kedua yaitu pelaksanaan seperti: pemberian edukasi mengenai pentingnya vaksinasi covid-19 sebagai upaya pencegahan covid 19, kegiatan lainnya juga dengan pelatihan dalam pembuatan disinfektan serta penyemprotan di ruang lingkungan lembaga. Tahap terakhir yaitu tahapan evaluasi yakni dengan memonitoring serta mewawancarai langsung mengenai informasi yang telah diberikan kepada mitra mengenai vaksinasi covid-19 serta pelatihan disinfektan tersebut.

\section{HASIL DAN PEMBAHASAN}

Kegiatan Sosialisasi pengabdian ini dengan memberikan edukasi mengenai pentingnya vaksinansi covid-19 serta dalam bentu pelatihan pembuatan disinfektan sebagai upaya pencegahan Covid-19 Di Aisyiah kukusan Depok. Kegiatan ini diawali dengan penyampaian materi mengenai covid-19 penyebab, gejala dan pencegahannya serta memberikan edukasi vaksinasi Covid-19 seperti yang terlihat pada gambar 1. Informasi mengenai vaksinansi covid-19 ini bertujuan untuk meluruskan informasi atau berita hoax mengeai vaksinasi agat masyarakat tidak ada lagi ketakutan mengenai pemberian vaksin (Kementerian Kesehatan RI, 2020) Serta juga mendapat informasi yang valid. Pemberian edukasi yang disampaikan yakni mengenai vaksinasi, cara kerja vaksinasi, kriteria yang boleh dan tidak boleh di vaksinasi, reaksi vaksinasi terhadap tubuh dan herd immunity.

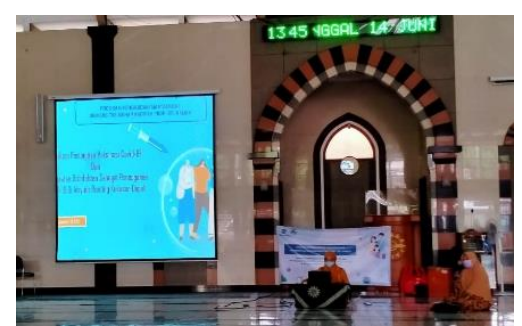

Gambar 1. Edukasi vaksinasi covid-19

Kegiatan selanjutnya dijelaskan mengenai langkah-langkah pembuatan disinfektan kemudian dilanjutkan dengan pembuatan disinfektan sebagai salah satu pencegahan covid-19. Pembuatan disinfektan dapat menggunakan bahan zat aktif yang bermacam-macam namun dalam pengabdian 
ini dilakukan hanya pada jenis hiploklorit dan fenol (World Health Organization, 2020b). Tim pengabdian kemudian langsung mendemonstrasikan cara pembuatan disinfektan dengan alat dan bahan yang sudah dipersiapkan sebelumnya. Seperti air dan larutan hipoklorit.(Athena, Laelasari, \& Puspita, 2020) kemudian bersama mitra membuat disinfektan seperti yang terlihat pada gambar 2 .

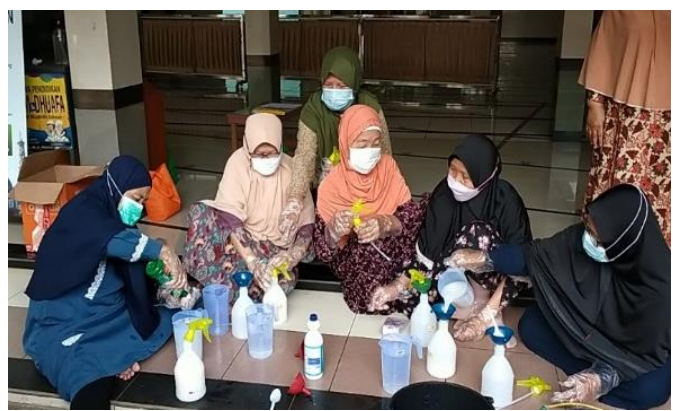

Gambar 2. Mitra membuat disinfektan

Hasil disinfektan yang telah dibuat kemudian digunakan pada kegiatan selanjutnya yaitu pelaksanaan penyemprotan di lingkungan lembaga yaitu masjid. Perlengkapan yang di semprot seperti keran air, tangga, pintu dan pegangannya, gerbang dan lainnya.

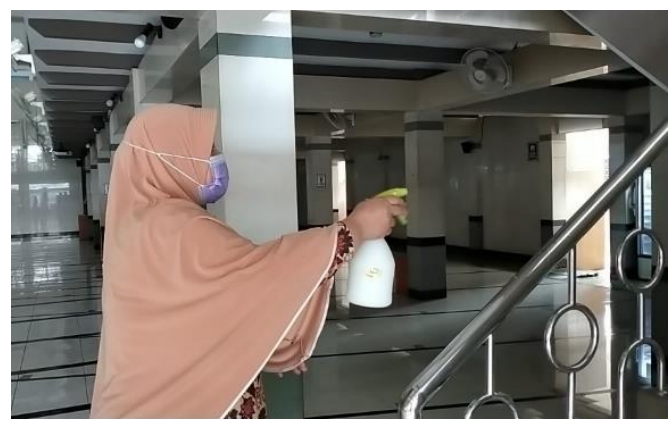

Gambar 3. Peserta menyemprotkan disinfektan pada area pegangan tangga

Cara mendisinfeksi alat boleh secara langsung disemprotkan pada suatu benda namun sebaiknya pada area yang lebih terkontaminasi lebih baik dimulai dengan mendisinfeksi terlebih dahulu dengan menggunkan kain yang dibasahi disinfektan terlebih dahulu. Tujuannya agar virus yang telah menempel tidak langsung tersebar ke udara.(World Health Organization, 2020a)

Setelah penyampaian materi mengenai vaksinansi dan pembuatan disinfektan, kelompok ibu-ibu aisyiah diberikan beberapa pertanyaan seperti:

1. Apakah mengetahui vaksinsasi dan cara kerjanya? $100 \%$ mitra menjawab mengetahui vaksinasi tetapi mereka tidak mengetahui bagaimana cara kinerjanya dalam tubuh.

2. Kegiatan apa saja yang dilakukan ibuibu dalam pencegahan penyebaran covid-19? Keseluruhan mengikuti protokol kesehatan seperti memakai masker, sering mencuci tangan dan menjaga jarak dan hanya $20 \%$ yang melakukan penyemprotan disinfektan di lingkungan tempat tinggalnya.

3. Dari mana memperoleh disinfektan? Keseluruhan menjawab dari RT stempat terkadang membeli secara mandiri dan belum pernah membuat disinfektan sendiri.

Kegiatan akhir ini di evaluasi oleh mitra bawa keseluruhan sangat senang dengan adanya kegiatan sosialisasi ini karena mereka mendapatkan infomasi yang jelas dan akurat mengenai vaksinasi covid-19 sehingga tidak simpang siur serta mereka juga mendapatkan informasi penting tentang pembuatan disinfektan yang ternyata mudah dan praktis.

\section{SIMPULAN DAN SARAN}

Kesimpulan pada kegiatan pengabdian ini bahwa kelompok aisyiah ranting kukusan Depok telah memperoleh informasi mengenai vaksinasi Covid 19 yang akurat serta kelompok aisyiah juga memperoleh pelatihan pembuatan disinfektan dan melakukan penyemprotan di lingkungan lembaga.

Saran yang diperoleh dari hasil evaluasi dalam kegiatan ini yaitu ditambahkannya media lain seperti banner atau flyer untuk menyampaikan informasi atau materi vaksinasi covid-19 serta perluasan wilayah kelompok aisyiah lainnya.

\section{DAFTAR RUJUKAN}

Athena, Athena, Laelasari, Eva, \& Puspita, Tities. (2020). PELAKSANAAN DISINFEKSI DALAM PENCEGAHAN PENULARAN COVID-19 DAN POTENSI RISIKO TERHADAP KESEHATAN DI INDONESIA. JURNAL EKOLOGI KESEHATAN. https://doi.org/10.22435/JEK.V19l1.3146

Daoust, J. F. (2020). Elderly people and responses to COVID-19 in 27 Countries. PLOS ONE, 15(7), e0235590. Retrieved from

https://doi.org/10.1371/journal.pone.0235 590

Kementerian Kesehatan RI. (2020). Peraturan menteri kesehatan republik indonesia nomor 84 tahun 2020 tentang pelaksanaan vaksinasi dalam rangka penanggulangan pandemi. 2019, 4.

Kusumaningtyas, Amelinda Pandu. (2021). 
Membaca Persepsi Masyarakat terhadap Vaksin Covid-19.

Rachman, Fajar Fathur, \& Pramana, Setia. (2020). Analisis Sentimen Pro dan Kontra Masyarakat Indonesia tentang Vaksin COVID-19 pada Media Sosial Twitter. Health Information Management Journal, 8(2), 100-109. Retrieved from https://inohim.esaunggul.ac.id/index.php/l NO/article/view/223/175

Syamaidzar, Syamaidzar. (2020). Review Vaksin Covid-19. Research Gate, (July), $1-15$.

World Health Organization. (2020a). WHO Coronavirus Disease (COVID-19) Dashboard.

World Health Organization. (2020b). WHO Timeline COVID-19. 